FEDERAL RESERVE BANK OF SAN FRANCISCO

WORKING PAPER SERIES

\title{
The Adjustments of Hours and Real Wages to Technology Shocks: Assessing the Role of Nominal Rigidities
}

\author{
Zheng Liu \\ Federal Reserve Bank of San Francisco \\ Louis Phaneuf \\ University of Quebec at Montreal \\ Glenn D. Rudebusch \\ Federal Reserve Bank of San Francisco
}

September 2011

Working Paper 2008-30

http://www.frbsf.org/publications/economics/papers/2008/wp08-30bk.pdf

The views in this paper are solely the responsibility of the authors and should not be interpreted as reflecting the views of the Federal Reserve Bank of San Francisco or the Board of Governors of the Federal Reserve System. 


\title{
The Adjustments of Hours and Real Wages to Technology Shocks: Assessing the Role of Nominal Rigidities*
}

\author{
Zheng Liu \\ Louis Phaneuf \\ Federal Reserve Bank of San Francisco \\ University of Quebec at Montreal
}

September 14, 2011

\begin{abstract}
Nominal rigidities are generally viewed as important for the transmission of monetary policy. We argue that nominal rigidities are important also for the transmission of technology shocks, especially for explaining their effects on hours and real wages. Evidence suggests that a positive technology shock leads to a short-run decline in labor hours and a gradual rise in real wages. We examine the ability of an RBC model augmented with real frictions, a pure sticky-price model, a pure sticky-wage model, and a model combining sticky prices and sticky wages in accounting for this evidence. We find that, according to this metric, the model with nominal wage and price rigidities is more successful than others. This finding is robust and holds true for a relatively small Frisch elasticity of hours and a relatively high frequency of price reoptimization that are consistent with microeconomic evidence.
\end{abstract}

JEL classification: E31, E32.

Keywords: Technology shock; nominal rigidities; labor market; monetary policy.

*Phaneuf acknowledges the financial support of FQRSC and SSHRC. An earlier draft of the paper was circulated under the title "Do Nominal Rigidities Matter for the Transmission of Technology Shocks?" The views expressed herein are those of the authors and do not necessarily reflect the views of the Federal Reserve Bank of San Francisco or the Federal Reserve System. 


\section{Introduction}

A widely held view following the seminal papers by Gray (1976), Fischer (1977), Phelps and Taylor (1977), and Taylor (1980) is that, rational espectations notwithstanding, nominal rigidities greatly matter for the transmission of monetary policy shocks. This view is also shared by the recent DSGE literature such as Christiano, Eichenbaum, and Evans (2005) and Smets and Wouters (2007), among others. However, the real business cycle (RBC) revolution launched by Kydland and Prescott (1982) suggests that business cycles are mainly driven by technology shocks, for which nominal rigidities are of little relevance. Would this be true, macroeconomists would be left with a dilemma: different types of business cycle models would be well suited for the analysis of certain types of shocks, not all. $^{1}$

In a provocative study, Galí (1999) presents evidence that a positive technology shock leads to persistent declines in hours. He argues that a dynamic stochastic general equilibrium (DSGE) model incorporating sticky prices and a weakly accommodative monetary policy to the technology shock accounts well for the evidence, while the standard RBC model does not. In response to Galí's (1999) critique of RBC models, Francis and Ramey (2005) show that an RBC model augmented with real frictions in the forms of habit formation and investment adjustment costs can generate a short-run decline in hours following a positive technology shock. Therefore, judging a particular model based on its ability to deliver a fall in hours following a technology improvement does not seem to be useful in assessing the empirical importance of alternative transmission mechanisms. ${ }^{2}$

In this paper, we argue that examining the joint dynamics of hours and real wages following a technology shock helps better evaluate competing transmission mechanisms in different models. We first summarize the empirical evidence on the responses of hours and real wages to technology shocks. We show that, although the empirical studies differ in their estimation methods, sample periods, and identification strategies, a consensus emerging from the empirical literature suggests that, following a positive technology shock, hours decline persistently and real wages rises modestly on impact and continues rising until reaching a new steady state level (e.g., Francis and Ramey, 2005; Basu, Fernald and Kimball, 2006; Liu and Phaneuf, 2007).

\footnotetext{
${ }^{1}$ See the early exchange between Summers (1986) and Prescott (1986).

${ }^{2}$ Christiano, Eichenbaum and Vigfusson (2004) provide evidence that a positive technology shock can lead to a rise in hours if log levels of hours instead of log differences in hours enter the structural vector autoregression (SVAR) model. Fernald (2007) offers a plausible reconciliation between these apparently conflicting results. He shows that if statistically significant and economically plausible trend breaks in hours and productivity are accounted for, a technology improvement unambiguously leads to a short-run decline of hours.
} 
We then examine the ability of a few alternative models in explaining the joint dynamics of hours and real wages observed in the data. We show that an RBC model augmented with real frictions may deliver a short-run decline of hours worked, but it also implies that the real wage responds strongly to a technology shock in the impact period and thus fails to generate the observed gradual rise in the real wage.

A sticky-price model similar to that studied by Galí (1999) also has difficulty in explaining the joint dynamics of hours and real wages. With a relatively weak accommodation of monetary policy to the technology shock, the sticky-price model can generate the short-run decline in hours. However, we show that the same conditions that lead to a decline in hours also lead to a short-run decline in the real wage, which is at odds with data.

We show that, in the sticky-price model, the sign of the real wage response on impact of a technology shock is determined by three factors. The real wage will fall on impact of a technology improvement if policy accommodation is not too strong, the Frisch elasticity of labor supply is relatively small, and the strategic complementarity in firms' pricing decisions is relatively strong.

This link between policy accommodation, the Frisch elasticity of hours and the decline in the real wage can be explained as follows. With sticky prices, a low Frisch elasticity of hours and a weak policy accommodation to the technology shock, the initial adjustments in consumption, and thus in the marginal utility of consumption are small. With a decline in hours and a rise in leisure, the marginal utility of leisure falls. Thus, the marginal rate of substitution between leisure and consumption falls on impact, and so does the real wage. For the real wage to increase following a positive technology shock, the degree of monetary policy accommodation to the technology shock and the Frisch elasticity of labor supply needs to be high. But the Frisch elasticity of hours is low according to micro level studies (e.g., Pencavel, 1985) whereas, the degree of policy accommodation to the technology shock, as we later show, is low for the postwar U.S. period.

The difficulty for the sticky-price model to explain the real wage responses to technology shocks leads us to extend Galí's (1999) framework by including monopolistically competitive households and sticky wages in our analytical model. In one version of the extended model, wages are sticky and prices are flexible. With sticky wages as the only source of nominal rigidities, we find that the real wage rises on impact of the technology shock, representing a step in the right direction relative to the sticky-price model. Nonetheless, a pure sticky-wage model does not predict a decline in hours worked. Since prices are flexible, the technology shock leads to a one-for-one decline in the price level and, in the absence of monetary policy accommodation (i.e., constant money supply), a one-for-one increase in output with the productivity so that hours stay constant. If monetary policy is partially accommodative to the shock, money supply increases and output rises even further so 
that hours also rise. Thus, regardless of the extent of monetary policy accommodation, the pure sticky-wage model does not predict a fall in hours.

The model with both sticky prices and sticky wages can generate the observed joint dynamics of hours and the real wage following a technology shock. The inability of a pure sticky-price model to generate an increase in the real wage is amended by allowing some nominal wage rigidity. We show that with sticky wages and sticky prices, a positive technology shock leads to a modest increase in the real wage on impact, as observed in the data. This result is robust to various values of the Frisch elasticity of labor supply and the degree of policy accommodation. On the other hand, the inability of a pure sticky-wage model to generate the observed decline in hours is overcome by introducing some nominal price rigidity, but then the degree of policy accommodation matters. If monetary policy is weakly accommodative, hours fall when technology improves, whereas if policy accommodation is relatively high, hours rise.

This leads us to examine whether monetary policy accommodation to the technology shock has been high or low during the postwar period. To answer this question, we provide evidence based on an examination of the relation between the U.S. money aggregates (M1 and M2) and two alternative measures of technology shocks. One is Basu, Fernald and Kimball's (2006) "purified" Solow residual which controls for non-technological factors such as variable input utilization rates, non-constant returns, and imperfect competition. The other is a measure constructed by Galí and Rabanal (2004), who use long-run restrictions in a SVAR model to identify the technology shock. With both measures, we show the degree of monetary policy accommodation to the technology shock is weak at best. We conclude that both nominal wage and price rigidities are crucial to understand the effects of a technology shock on hours and the real wage.

We report one last substantive finding. We show that with a high frequency of price reoptimization as suggested by recent micro level studies (e.g., Bils and Klenow, 2004; Klenow and Kryvtsov, 2008; Nakamura and Steinsson, 2008), the responses of hours and the real wage to a technology shock implied by the model with sticky wages and sticky prices remain consistent with empirical evidence.

Therefore, our findings and the recent strand of literature on the transmission of monetary policy shocks both deliver a coherent message: nominal wage and price rigidities are of primary importance for the transmission of monetary policy and technology shocks in DSGE settings.

The paper is organized as follows. Section 2 summarizes some empirical evidence about the effects of technology shocks on hours and real wages. Section 3 presents a real business cycle (RBC) model with habit formation to illustrate the inability of an RBC model in capturing the observed labor market responses to technology shocks. Section 4 develops a DSGE model with sticky prices. 
There, we derive closed-form solutions and assess the plausibility of the sticky-price model to match empirical evidence on hours and real wages. Section 5 examines the role of sticky nominal wages in the transmission of technology shocks. We begin with a pure sticky-wage model to illustrate the mechanism and then assess the ability of the model with both sticky prices and sticky wages in replicating the empirical evidence on hours and real wages. Section 6 presents evidence about the extent of monetary policy accommodation to technology shocks. Section 7 concludes.

\section{The Adjustments of Hours and Real Wages Following Technol- ogy Shocks}

Technology shocks are shown to be important for business cycles, not just in the RBC literature but also in the recent DSGE literature (e.g., Smets and Wouters, 2007; Justiniano and Primiceri, 2008; Liu, Waggoner, and Zha, 2011). ${ }^{3}$ Woodford (2009) echoes the view that technology shocks are important. He states that "it is now widely accepted that real disturbances are an important source of economic fluctuations," whereas the view "that business fluctuations can be largely attributed to exogenous random variations in monetary policy has few if any remaining adherents."

To document what happens after a technology shock, we summarize the relevant findings in the recent empirical literature. We argue that, despite of different estimation approaches, different sample periods, and different identification strategies, a consensus emerges from these empirical studies concerning the responses of hours worked and the real wage to a technology shock.

A first piece of evidence about the response of employment following a technology shock can be found in the early work of Shapiro and Watson (1988) on SVAR models. Using quarterly U.S. postwar data from 1951:1 to 1985:4, they estimate SVAR models in which long-run restrictions serve to identify a technology shock. They provide two sets of estimates: one from a SVAR with a stochastic trend in hours, and the other from a SVAR with a deterministic trend in hours. In both cases, they find evidence of a short-run decline of hours following a technology improvement. ${ }^{4}$ However, they do not discuss the implications of their findings for alternative macroeconomic theories.

\footnotetext{
${ }^{3}$ Smets and Wouters (2007) report that productivity shocks explain more than 30 percent of the forecast error variance decomposition of output at the 10-quarter horizon. Ireland's (2011) estimates suggest that technology shocks contribute to over 60 percent of output fluctuations at the same horizon. Galí, Smets and Wouters (2011) establish that productivity shocks contribute between 46 and 59 percent of the variance decomposition of output at the 10quarter horizon and between 32 and 40 percent of the variance decomposition of real wages. By any standards, those are large numbers.

${ }^{4}$ See Shapiro and Watson (1988), Figures 2 and 5.
} 
Galí (1999) brings this consideration to the forefront of his analysis. Focusing on the sources of the near-zero correlation between hours and labor productivity, he provides evidence showing that technology shocks induce a negative correlation between these variables while non-technology shocks trigger a positive correlation. These findings are obtained from estimated SVAR models that identify a technology shock as the only disturbance affecting the long-run level of labor productivity. A technology improvement generates a short-run decline of hours and an increase in labor productivity. According to Galí, the short-run fall in hours following a technology shock is hardly reconcilable with the predictions of the standard RBC model, whereas it appears consistent with the predictions of a new keynesian model featuring sticky prices and a weak accommodation of monetary policy to the technology shock.

Basu, Fernald and Kimball (2006) also offer evidence of a short-run decline in hours following a positive technology shock using a "purified Solow residual" controlling for non-technological factors that may affect measured total factor productivity. While their approach does not require the use of long-run identifying restrictions, their findings are nonetheless consistent with Galí's results: technology improvements have short-run contractionary effects on employment.

Galí's (1999) approach has been questioned by Christiano, Eichenbaum and Vigfusson (2004) on the basis that hours worked should enter the SVAR in levels rather than first-differences. Imposing the same long-run restrictions as in Galí to identify the technology shock, they show that hours rise in response to a positive technology shock with hours in levels in the SVAR.

Fernald (2007) attempts a reconciliation of these apparently conflicting results. He combines the log-level and log-difference of per capita hours with statistically and economically significant trend breaks in productivity and finds that the results are much less sensitive to the specific treatment of hours in the SVARs: hours worked systematically decline following a technology improvement.

Drawing the distinction between neutral technology and investment-specific technology shocks, Fisher (2006, Figure 7) looks at the effects of both types of shocks on hours worked. Using a SVAR approach with long-run restrictions identifying the two types of technology shocks, he reports evidence for the years 1955:I to 1979:II of a statistically significant short-run decline of hours worked in response to positive innovations in both types of shocks. His findings are robust to alternative specifications for hours, whether hours worked are measured in levels, first-differences or are detrended in the SVAR. The evidence is somewhat less conclusive for the years 1982:III to 2000:IV, as he finds that the impulse responses of hours are either statistically insignificant or negative.

Francis and Ramey (2005) present evidence about real wage adjustment following a technology shock. They use a SVAR approach where long-run restrictions help identify the technology shock. 
They show that in the wake of a one-percent positive technology shock, the real wage increases by only 0.4 percent and then gradually rises to its new long-run level. Basu, Fernald and Kimball (2006) report similar evidence about real wages using their "purified" measure of aggregate technology change.

Going a step further, Liu and Phaneuf (2007) estimate SVARs with long-run identifying restrictions and examine how the real wage responds to a technology shock depending on the treatment of hours worked in the SVAR. They conclude that whether hours are in levels or first-differences, the real wage modestly rises on impact of a positive technology shock, and continues rising thereafter.

To conclude this section, we present evidence summarizing the consensus view about the effects of technology shocks on hours and the real wage. We estimate a four-variable SVAR model that includes the log-difference of labor productivity, the log-difference of nominal wages, the logdifference of nominal prices and the log-difference of per capita hours. Our sample of data, which is quarterly, covers the period 1949:II to 2003:IV. The technology shock is identified as the only disturbance affecting the long-run level of labor productivity. The results are displayed in Figure 1. The figure also displays the $95 \%$ confidence bands (the shaded areas) estimated from the SVAR model. Following a positive one-percent technology shock, hours decline persistently, with an initial response of $-0.4 \%$. The real wage on impact of the positive technology shock increases by $0.3 \%$, and continues rising until reaching a permanently higher steady state level.

The evidence presented in this section suggests that hours decline persistently following a positive one-percent technology shock, while the real wage increases modestly on impact, and continues rising until reaching a permanently higher steady state level.

\section{Technology Shocks in a Real Business Cycle Model With Habit Formation}

This section examines an RBC model augmented with habit formation. ${ }^{5}$ Habit formation slows the adjustment of consumption and thus helps generate a decline in labor hours following a positive technology shock (e.g., Francis and Ramey, 2005). However, the RBC model with habit formation fails to generate the observed gradual rise in real wages.

\footnotetext{
${ }^{5}$ We do not consider investment adjustment costs since our model abstracts from capital accumulation, both our main arguments would remain the same with costly investment adjustment.
} 
To see this, consider a representative-agent economy, in which the household has the utility function

$$
\mathrm{E} \sum_{t=0}^{\infty} \beta^{t}\left[\log \left(C_{t}-b \bar{C}_{t-1}\right)-V\left(N_{t}\right)\right]
$$

where $\beta \in(0,1)$ is a subjective discount factor, $C_{t}$ is the household's individual consumption, $\bar{C}_{t}$ is aggregate consumption, $N_{t}$ is labor hours, and $b>0$ measures the importance of habit formation. Suppose, for simplicity, that the production technology takes the form $C_{t}=A_{t} N_{t}$, where $A_{t}$ is a technology shock and follows a random walk process so that

$$
A_{t}=A_{t-1} \exp \left(\varepsilon_{t}\right)
$$

where $\varepsilon_{t}$ is a mean-zero, iid normal process, with a finite variance $\sigma_{a}^{2}$.

The optimal labor-leisure decision implies that

$$
V^{\prime}\left(N_{t}\right)\left(C_{t}-b C_{t-1}\right)=w_{t}
$$

where $w_{t}$ denotes the real wage. In equilibrium, the real wage equals the marginal product of labor. Thus, we have

$$
V^{\prime}(N)\left(A_{t} N_{t}-b A_{t-1} N_{t-1}\right)=A_{t} .
$$

Dividing through by $A_{t}$ and using the technology shock process, we obtain

$$
V^{\prime}(N)\left[N_{t}-b N_{t-1} \exp \left(-\varepsilon_{t}\right)\right]=1
$$

This equation gives a unique solution for labor hours in equilibrium. In the special case with no habit formation (i.e., with $b=0$ ), a technology shock has no effect on hours since under our preference and technology specifications (log-utility in consumption and constant returns technology), the income effect and the substitution effect exactly offset. With habit formation (i.e., with $b>0$ ), Eq. (4) shows that a positive technology shock leads to a decline in hours on impact. Thus, an $\mathrm{RBC}$ model augmented with habit formation is capable of generating the observed contractionary employment effect of technology shocks. ${ }^{6}$

In this example, the real wage rises one-for-one with the technology shock (since $w_{t}=A_{t}$ ). In contrast, in the data, the real wage rises modestly on impact and continues to increase until reaching a permanently higher steady state. In a more general RBC model with capital accumulation and investment adjustment costs such as the one studied by Francis and Ramey (2005), one can still obtain a decline in labor hours. However, the real wage in that model overshoots its steady

\footnotetext{
${ }^{6}$ With capital accumulation and without habit formation, hours will rise following a positive technology shock. But still, if real frictions are strong enough, hours will fall.
} 
state level on impact. Thus, although an RBC model with real rigidities can potentially explain the contractionary effects of technology shocks on employment, it has difficulties explaining the observed responses of real wages following a technology shock.

\section{The Transmission of Technology Shocks in the Sticky-Price Model}

This section presents a stylized monetary business-cycle model with sticky prices and examine the model's predicted effects of technology shocks on hours and the real wage.

\subsection{The Model Economy}

The economy is populated by a large number of identical, infinitely-lived households, and a large number of firms, each producing a differentiated product. The representative household is endowed with one unit of time and derives utility from consumption, real money balances, and leisure time. The consumption good is a composite of the differentiated products. Production of each type of differentiated good requires labor as the only input and is subject to a productivity shock. While the labor market is perfectly competitive, the goods market is monopolistically competitive. Firms' pricing decisions are staggered in the spirit of Calvo (1983), although our main results do not hinge upon this specific form of price rigidity.

\subsubsection{The Representative Household}

The representative household has preferences defined by the following utility function:

$$
\mathrm{E} \sum_{t=0}^{\infty} \beta^{t}\left[\log C_{t}+\Phi \log \frac{M_{t}}{P_{t}}-V\left(N_{t}\right)\right]
$$

where $\mathrm{E}$ is an expectations operator, $\beta \in(0,1)$ is a subjective discount factor, $C_{t}$ denotes consumption, $M_{t} / P_{t}$ denotes real money balances, and $N_{t}$ denotes labor hours.

In each period $t$, the household faces a budget constraint

$$
P_{t} C_{t}+M_{t}+\mathrm{E}_{t} D_{t, t+1} B_{t+1} \leq W_{t} N_{t}+\Pi_{t}+M_{t-1}+B_{t}-T_{t},
$$

where $P_{t}$ is the price level, $W_{t}$ is the nominal wage rate, $\Pi_{t}$ is a claim to all firms' profits, and $T_{t}$ is a lump-sum tax. The term $B_{t+1}$ denotes the holdings of a one-period state-contingent nominal bond that pays one unit of currency in period $t+1$ if a particular event is realized, $D_{t, t+1}$ is the period- $t$ price of such a bond divided by the probability of the appropriate state, so that $\mathrm{E}_{t} D_{t, t+1} B_{t+1}$ is the total cost of state-contingent bonds. 
The consumption basket is given by

$$
C_{t}=\left[\int_{0}^{1} Y_{t}(j)^{\frac{\varepsilon_{p}-1}{\varepsilon_{p}}} d j\right]^{\frac{\varepsilon_{p}}{\varepsilon_{p}-1}},
$$

where $Y_{t}(j)$ denotes the output of type- $j$ good and $\varepsilon_{p}>1$ is the elasticity of substitution between differentiated products. The household's expenditure-minimization problem results in a demand schedule for a type- $j$ good:

$$
Y_{t}^{d}(j)=\left(\frac{P_{t}(j)}{P_{t}}\right)^{-\varepsilon_{p}} C_{t}
$$

where $P_{t}(j)$ denotes the price of good $j$, and the price level $P_{t}$ is related to individual prices through $P_{t}=\left[\int_{0}^{1} P_{t}(j)^{1-\varepsilon_{p}} d j\right]^{\frac{1}{1-\varepsilon_{p}}}$.

Solving the household's utility-maximization problem results in a labor supply equation, an intertemporal Euler equation, and a money demand equation, given respectively by

$$
\begin{aligned}
\frac{W_{t}}{P_{t}} & =V^{\prime}\left(N_{t}\right) C_{t}, \\
D_{t, \tau} & =\beta^{\tau-t} \frac{C_{t}}{C_{\tau}} \frac{P_{t}}{P_{\tau}},
\end{aligned}
$$

and

$$
\Phi \frac{1}{M_{t}}+\beta \mathrm{E}_{t} \frac{1}{P_{t+1} C_{t+1}}=\frac{1}{P_{t} C_{t}}
$$

\subsubsection{Firms and Optimal Price-Setting}

A good of type $j \in[0,1]$ is produced using labor as the input, with a production function given by

$$
Y_{t}(j)=A_{t} N_{t}(j)
$$

where $A_{t}$ denotes a productivity shock that is common to all firms, and $N_{t}(j)$ is the homogeneous labor used by firm $j$. The shock follows the stochastic process described in Eq (2).

Firms are price-takers in the input markets and monopolistic competitors in the product markets. They set prices in a staggered fashion in the spirit of Calvo (1983). In particular, in period $t$, all firms receive an iid random signal that determines whether or not they can set a new price. The probability that firms can adjust prices is $1-\alpha_{p}$. By the law of large numbers, a fraction $1-\alpha_{p}$ of firms can set new prices in any given period.

If firm $j$ can set a new price in period $t$, it chooses a price $P_{t}(j)$ to maximize an expected present value of its profits

$$
\mathrm{E}_{t} \sum_{\tau=t}^{\infty} \alpha_{p}^{\tau-t} D_{t, \tau}\left[P_{t}(j)-V_{\tau}\right] Y_{\tau}^{d}(j),
$$


where $V_{\tau}=W_{\tau} / A_{\tau}$ is the unit production cost, and $Y_{\tau}^{d}(j)$ is the demand schedule described in (8). Solving the profit maximizing problem results in an optimal pricing decision rule

$$
P_{t}^{*}(j)=\mu_{p} \frac{\mathrm{E}_{t} \sum_{\tau=t}^{\infty} \alpha_{p}^{\tau-t} D_{t, \tau} V_{\tau} Y_{\tau}^{d}(j)}{\mathrm{E}_{t} \sum_{\tau=t}^{\infty} \alpha_{p}^{\tau-t} D_{t, \tau} Y_{\tau}^{d}(j)},
$$

where $\mu_{p}=\varepsilon_{p} /\left(\varepsilon_{p}-1\right)$ measures the steady-state markup. The optimal price is thus a markup over a weighted average of the marginal costs in the current and future periods during which the price is expected to remain in effect.

Solving the cost-minimizing problem of firm $j$ yields the demand for labor $N_{t}^{d}(j)=Y_{t}^{d}(j) / A_{t}$. The aggregate demand for labor is then given by

$$
N_{t}^{d}=\frac{1}{A_{t}} \int_{0}^{1} Y_{t}^{d}(j) d j=\frac{G_{t} C_{t}}{A_{t}},
$$

where $G_{t}=\int_{0}^{1}\left[P_{t}(j) / P_{t}\right]^{-\varepsilon_{p}} d j$ measures price dispersion. Thus, if the rise in aggregate demand cannot catch up with productivity improvement, the aggregate demand for labor will fall.

\subsubsection{Monetary Policy}

Following Galí (1999), we assume that the monetary authority is allowed, but not required to adjust the growth rate of money stock in response to changes in productivity shocks. Specifically, we assume

$$
\mu_{t}=(1-\rho) \bar{\mu}+\rho \mu_{t-1}+\gamma \varepsilon_{t},
$$

where $\mu_{t}=\log \left(M_{t}^{s} / M_{t-1}^{s}\right)$ denotes the growth rate of money supply, $\bar{\mu}$ is the mean money growth, and $\gamma \neq 0$ implies a systematic response of monetary policy to technology shocks.

\subsubsection{Equilibrium}

Given the monetary policy described in (16), an equilibrium consists of allocations $C_{t}, N_{t}, B_{t+1}$, and $M_{t}$ for the representative household; allocations $Y_{t}(j)$ and $N_{t}(j)$, and price $P_{t}(j)$ for producer $j \in[0,1]$; together with prices $D_{t, t+1}, \bar{P}_{t}$, and wage $W_{t}$, that satisfy the following conditions: (i) taking the prices and the wage as given, the household's allocations solve its utility maximizing problem; (ii) taking the wage and all prices but its own as given, each producer's allocations and price solve its profit maximizing problem; and (iii) markets for bonds, money, labor, and the composite goods clear.

We focus on a symmetric equilibrium in which all firms who can adjust prices in a given period make identical pricing decisions. Thus, we do not have to keep track of the firm-specific index $j$ and we can write the pricing decisions as $P_{t}^{*}$ in place of $P_{t}^{*}(j)$. 


\subsection{The Sticky-Price Channel}

We now examine the sticky-price channel for the transmission of technology shocks. We examine, both analytically and numerically the responses of hours and real wages following a technology shock.

\subsubsection{Theoretical Properties of the Sticky-Price Model}

We first examine the theoretical properties of the sticky-price model for the adjustment of hours and the real wage following a technology shock and we assess the plausibility of these theoretical implications in light of the empirical evidence we have discussed earlier in the paper. In the next subsection, we evaluate the model's performance along these dimensions under empirically plausible values of the parameters.

For our purpose, we consider small shocks so that the equilibrium conditions can be approximated by log-linearizing around a zero-inflation steady state. ${ }^{7}$ Further, for analytical convenience, we set $\rho=0$ in the money growth rule (16), so that deviations of the money growth rate from its steady state level is proportional to productivity growth. Or equivalently, given that the productivity shock follows a random walk process, so does the money stock under the assumption that $\rho=0$. This allows us to characterize the equilibrium dynamics using a closed-form solution. We relax this assumption when we assess the quantitative implications of the sticky-price model in the next subsection.

We begin with the Phillips-curve relation obtained from log-linearizing the optimal pricing decision rule (14)

$$
\pi_{t}=\beta \mathrm{E}_{t} \pi_{t+1}+\kappa_{p}\left(c_{t}-\bar{c}_{t}\right),
$$

where lower-case variables denote the log-deviations of the upper-case variables from steady state, $\pi_{t}=p_{t}-p_{t-1}$ denotes the inflation rate, $\bar{c}_{t}=a_{t}$ is the natural rate of output. The parameter $\kappa_{p}=\lambda_{p}(1+\eta)$ determines the response of real marginal cost to changes in output, where $\eta=$ $V^{\prime \prime}(N) N / V^{\prime}(N)$ is the inverse labor-supply elasticity and $\lambda_{p}=\left(1-\beta \alpha_{p}\right)\left(1-\alpha_{p}\right) / \alpha_{p}$ is the elasticity of pricing decisions with respect to real marginal cost. Note that $\kappa_{p}$ increases with $\eta$, the inverse labor supply elasticity. A smaller labor supply elasticity implies a larger value of $\eta$ and thus a larger $\kappa_{p}$, so that the marginal cost is more responsive to changes in aggregate demand, and there is less endogenous nominal price rigidity.

Next, we log-linearize the intertemporal money demand decision (11) to obtain

$$
p_{t}+c_{t}=(1-\beta) m_{t}+\beta \mathrm{E}_{t}\left(p_{t+1}+c_{t+1}\right) .
$$

\footnotetext{
${ }^{7}$ Allowing for positive steady-state inflation does not change the qualitative results (not reported).
} 
Under our assumption that $\rho=0$ in the monetary policy rule (16), the money supply follows a random-walk process, as does the technology shock. Then, (18) reduces to

$$
p_{t}+c_{t}=(1-\beta) \sum_{j=0}^{\infty} \beta^{j} \mathrm{E}_{t} m_{t+j}=m_{t} .
$$

Note that, this apparently static aggregate demand relation is not an ad hoc assumption, but rather an equilibrium outcome. It is obtained under the assumptions of separable period-utility function, log-utilities in consumption and real money balances, and the random-walk property of money stocks inherited from the technology shock process.

The system of equilibrium conditions (17) and (19), along with the monetary policy rule $m_{t}=$ $\gamma a_{t}$ can be combined to obtain a solution for the dynamics of the price level. This is given by

$$
p_{t}=\theta_{p} p_{t-1}+\left(1-\theta_{p}\right)(\gamma-1) a_{t}
$$

where $\theta_{p}$ is the stable root of the quadratic polynomial $\beta \theta^{2}-\left(1+\beta+\kappa_{p}\right) \theta+1=0$. Thus, the price level falls on impact of a positive technology shock as long as $\gamma<1$. A larger $\theta_{p}$ implies greater strategic complementarity in firms' pricing and thus more persistence in the price (and inflation) dynamics and a smaller response of the price level (and of inflation) to technology shocks.

Given the solution for $p_{t}$, we obtain the solution for $c_{t}$ by using (19). It then follows from $n_{t}=c_{t}-a_{t}$ that the solution for employment is given by

$$
n_{t}=\theta_{p} n_{t-1}+(\gamma-1) \theta_{p} \varepsilon_{t} .
$$

Therefore, as stated by Galí (1999), a technology improvement leads to a fall in employment if and only if $\gamma<1$. Further, for a larger value of $\theta_{p}$, employment becomes more persistent and, for any given $\gamma \neq 1$, more responsive to the technology shock.

As a point of departure from Galí (1999), we also examine the response of the real wage to a technology shock. Using the method of undetermined coefficients, we obtain the initial response of the real wage on impact of a technology shock which we denote $\omega_{0}$ :

$$
\omega_{0}=1-\theta_{p}(1+\eta)(1-\gamma)
$$

The impact effect of a technology shock on the real wage is thus ambiguous, depending on the parameter values. The real wage falls on impact if monetary policy accommodation to the technology shock is weak (i.e., $\gamma$ is small), the Frisch elasticity of hours is small (i.e., $\eta$ is large), or the strategic complementarity is strong (i.e., $\theta_{p}$ is large).

Thus, in response to a positive technology shock, the stickiness in price-setting implies sluggishness in output adjustment as long as $\gamma$ is relatively small. For a small value of $\gamma$, output adjustment 
cannot catch up with the technology improvement, leading to a lower demand for labor at any given real wage. The lower demand for labor puts a downward pressure on the equilibrium real wage. Since $c_{t}$ rises, there is also an income effect on labor supply that tends to offset the fall in the real wage, so that the net effect is ambiguous. Specifically, the net effect on the real wage depends on the strength of the income effect (that depends negatively on the endogenous price stickiness measured by $\theta_{p}$ and positively on the degree of monetary policy accommodation measured by $\gamma$ ) relative to that of the substitution effect (that depends positively on the curvature coefficient of the labor supply curve $\eta$ ).

For plausible parameter values, as we show below, the real wage indeed falls along with employment in the sticky-price model. As the price level falls (for $\gamma<1$ ), the decline in the real wage after the shock implies an even stronger decline in the nominal wage, making it difficult for the sticky-price model, by itself, to explain the modest rise in the real wage on impact of the technology shock.

\subsubsection{Calibration}

We now assess the quantitative predictions of the sticky-price model under empirically plausible parameter values. We first consider a set of baseline calibrated parameters, and then examine the robustness of the results.

The parameters to be calibrated include $\beta$, the subjective discount factor; $\alpha_{p}$, the Calvo probability of price non-reoptimization; $\varepsilon_{p}$, the elasticity of substitution between differentiated products; $\eta$, the inverse elasticity of labor supply; and the monetary policy parameters $\rho$ and $\gamma$. The calibrated values are summarized in Table 1.

Since we have a quarterly model in mind, we set $\beta=0.99$ so that the steady state annual real interest rate is 4 percent. We set $\alpha_{p}=0.75$ so that the average duration of the price contracts is 4 quarters. The parameter $\varepsilon_{p}$ determines the steady-state markup of prices over marginal cost, with the markup given by $\mu_{p}=\varepsilon_{p} /\left(\varepsilon_{p}-1\right)$. Recent studies by Basu and Fernald (2002) suggest that the value-added markup, controlling for factor capacity utilization rates, is about 1.05; whereas without any utilization correction, the value-added markup is about 1.12. Some other studies suggest a higher value-added markup of about 1.2 (without corrections for factor utilization) (e.g., Rotemberg and Woodford, 1997). Since we do not focus on variations in factor utilization, in light of these studies, we set $\varepsilon_{p}=10$ so that $\mu_{p}=1.1$. The parameter $\eta$ corresponds to the inverse labor supply elasticity. Most empirical studies suggest that this elasticity is small and lies well below one, so that $\eta$ is above one. We set $\eta=2$ as a benchmark value and also consider a range of $\eta$ between 1 and 5, corresponding to a labor supply elasticity in the range between 0.2 and 1, consistent with 
evidence on the elasticity of labor supply obtained from micro data (e.g., Pencavel, 1986). ${ }^{8}$ For the purpose of illustration, we set $\rho=0.6$ and $\gamma=0$ as a benchmark. In our sensitivity analysis, we allow $\gamma$ to vary in the broad range between 0 and 1 .

Figure 2 plots the impulse responses of hours and the real wage following a positive technology shock under the calibrated parameters. Evidently, the real wage falls along with employment. The fall in hours is supported by empirical evidence, but the decline in the real wages is not.

Figure 3 plots the impact effects of the shock on hours and the real wage as the policy parameter $\gamma$ varies from 0 to 1 and the inverse labor supply elasticity $\eta$ varies from 1 to 5 . The figure reveals that the sticky-price model consistently predicts the fall in hours under all configurations of these parameters. The impact effect on the real wage is more ambiguous. Consistent with our analytical solutions, the impact effect on the real wage tends to be more negative if $\gamma$ is small or $\eta$ is large. Given the smallest value of $\eta$ we consider plausible (i.e., $\eta=1$ ), the sticky-price model is able to generate a rise in the real wage if $\gamma$ is about 0.3 or higher. However, to be able to generate an initial increase in the real wage of about the size we have documented in the section $2, \gamma$ would have to be at least 0.5 . With a higher $\eta, \gamma$ would have to be even higher, so that monetary policy would be quite accommodative to the technology shock. We provide in section 6 empirical evidence about the extent of accommodation of monetary policy to the technology shock.

\section{The Role of Nominal Wage Rigidities}

We now introduce sticky nominal wages in the model and examine the sticky-wage channel in the transmission of technology shocks.

We assume that the labor market, like the goods market, is monopolistically competitive. There is a continuum of households, each endowed with a differentiated labor skill indexed by $i \in[0,1]$, with a utility function similar to (5) (with all variables in the utility function indexed by $i$ ). Production of goods requires a composite labor as the input, and is subject to a productivity shock. The production function is the same as in (12), with the composite labor given by

$$
N_{t}=\left(\int_{0}^{1} N_{t}(i)^{\frac{\varepsilon_{w}-1}{\varepsilon_{w}}} d i\right)^{\frac{\varepsilon_{w}}{\varepsilon_{w}-1}},
$$

where $\varepsilon_{w}>1$ is the elasticity of substitution between differentiated skills. Solving firms' costminimizing problem results in a demand schedule for labor skill of type $i$. It is given by

$$
N_{t}^{d}(i)=\left(\frac{W_{t}(i)}{W_{t}}\right)^{-\varepsilon_{w}} N_{t}
$$

\footnotetext{
${ }^{8}$ The results are robust even when we extend the lower bound of $\eta$ to 0.5 (not reported).
} 
where $W_{t}(i)$ is the nominal wage for a type $i$ labor skill, and $W_{t}$ is the wage index that is related to individual wages by $W_{t}=\left(\int_{0}^{1} W_{t}(i)^{1-\varepsilon_{w}} d i\right)^{\frac{1}{1-\varepsilon_{w}}}$.

In each period, each household receives an iid random signal that enables it to adjust its nominal wage with probability $1-\alpha_{w}$, taking the demand schedule for labor skill (24) as given. It follows from the law of large numbers that, in each period, a fraction $1-\alpha_{w}$ of all households can set new wages. The optimal wage decision rule is given by

$$
W_{t}^{*}(i)=\mu_{w} \frac{\mathrm{E}_{t} \sum_{\tau=t}^{\infty} \alpha_{w}^{\tau-t} D_{t, \tau} M R S_{\tau}(i) N_{\tau}^{d}(i)}{\mathrm{E}_{t} \sum_{\tau=t}^{\infty} \alpha_{w}^{\tau-t} D_{t, \tau} N_{\tau}^{d}(i)},
$$

where $\mu_{w}=\varepsilon_{w} /\left(\varepsilon_{w}-1\right)$ measures the steady-state wage markup, and $M R S=V^{\prime}(N) C$ denotes the marginal rate of substitution between leisure and consumption. The optimal wage is thus a constant markup over a weighted average of the MRS's in the current and future periods during which the wage is expected to remain in effect.

We focus on log-linearized equilibrium conditions around a zero-inflation steady state. In the model with both sticky prices and sticky wages, the equilibrium conditions are summarized below:

$$
\begin{gathered}
\pi_{t}=\beta \mathrm{E}_{t} \pi_{t+1}+\lambda_{p} \tilde{\omega}_{t} \\
\pi_{w t}=\beta \mathrm{E}_{t} \pi_{w, t+1}+\frac{\lambda w}{1+\eta \varepsilon_{w}}\left[(1+\eta) \tilde{c}_{t}-\tilde{\omega}_{t}\right], \\
\tilde{\omega}_{t}=\tilde{\omega}_{t-1}+\pi_{w t}-\pi_{t}-\Delta a_{t}, \\
(1-\beta)\left(\tilde{c}_{t}-\tilde{m}_{t}\right)=\beta \mathrm{E}_{t}\left(\pi_{t+1}+\Delta \tilde{c}_{t+1}\right), \\
\Delta \tilde{m}_{t}=\mu_{t}-\pi_{t}-\Delta a_{t},
\end{gathered}
$$

along with the monetary policy rule (16). In these expressions, $\pi_{w t}=w_{t}-w_{t-1}$ denotes the wage inflation rate, $\tilde{\omega}_{t}$ denotes the real-wage gap, $\tilde{c}_{t}$ denotes the output gap, $\tilde{m}_{t}$ denotes the real-balance gap, and $\lambda_{w}=\left(1-\beta \alpha_{w}\right)\left(1-\alpha_{w}\right) / \alpha_{w}$ is a parameter that determines the responsiveness of wagesetting decisions to the marginal rate of substitution between leisure and consumption. Equations (26) and (27) are derived from optimal price- and wage-setting decisions and are sometimes known as the price-Phillips curve and the wage-Phillips curve, respectively. Equation (28) describes the law of motion of the real-wage gap. Equation (29) is derived from the money demand relation. Finally, (30) describes the law of motion of the real-balance gap.

\subsection{The Sticky-Wage Channel}

To examine the potential ability of the model with nominal wage rigidity in explaining the evidence about the response of hours and the real wage to a technology shock, we consider various degrees 
of price rigidity. We begin with the extreme case of perfectly flexible price decisions (i.e., $\alpha_{p}=0$ ). In this case, the pricing decision is given by $p_{t}=w_{t}-a_{t}$, so that the real wage rises one-for-one with the technology shock, and the real-wage gap is closed. The sharp increase in the real wage is inconsistent with the evidence of a much smaller percentage increase in the real wage following a technology shock.

To help obtain the equilibrium dynamics of hours, the price level, and the nominal wage, we assume that the monetary authority follows the money growth rule (16) and that $\rho=0$.

First, since the real-wage gap is closed under flexible prices, we can rewrite the wage-Phillips curve relation $(27)$ as

$$
\pi_{w t}=\beta \mathrm{E}_{t} \pi_{w, t+1}+\kappa_{w}\left(c_{t}-a_{t}\right) .
$$

where $\kappa_{w}=\lambda_{w}(1+\eta) /\left(1+\eta \varepsilon_{w}\right)$. Using the pricing decision equation $p_{t}=w_{t}-a_{t}$, this equation can be rewritten in terms of price inflation:

$$
\pi_{t}+\Delta a_{t}=\beta \mathrm{E}_{t}\left(\pi_{t+1}+\Delta a_{t+1}\right)+\kappa_{w}\left(c_{t}-a_{t}\right) .
$$

Solving for the price level, we obtain

$$
p_{t}=\theta_{w} p_{t-1}+\left(1-\theta_{w}\right)(\gamma-1) a_{t}-\theta_{w} \Delta a_{t}
$$

where $\theta_{w} \in(0,1)$ is the stable root of the quadratic polynomial $\beta \theta^{2}-\left(1+\beta+\kappa_{w}\right) \theta+1=0$. Given the solution for $p_{t}$, we use the aggregate demand relation (19) to obtain $c_{t}$, and the production function to obtain $n_{t}$. The solution for hours is given by

$$
n_{t}=\theta_{w} n_{t-1}+\theta_{w} \gamma \varepsilon_{t} .
$$

Thus, with perfectly flexible prices and sticky nominal wages, the hours response to technology shocks is non-negative as long as $\gamma \geq 0$. A pure sticky-wage cannot be consistent with the evidence of a short-run decline in hours worked following a positive technology shock.

We conclude that the sticky-wage model's predicted adjustment in the real wage does not align well with the empirical evidence. In the data, the real wage rises modestly on impact, and continues rising thereafter until reaching the new steady state. In the model, the real wage rises instantaneously to the new steady state on impact of the shock. This problem occurs mainly because price adjustments are assumed to be perfectly flexible. Moreover, the sticky-wage model fails to generate a fall in hours when technology improves.

\subsection{The Joint Implications of Sticky Wages and Sticky Prices}

We now consider the more general case with some price rigidity along with the nominal wage rigidity. In this case, the equilibrium dynamics are the solution to the system of equilibrium 
conditions (26)-(30), along with the monetary policy rule (16). To solve the model, we use the calibrated parameter described in the previous section, and calibrate two additional parameters that are unique to nominal wage rigidity: we set $\alpha_{w}=0.75$ so that the average duration of nominal wage contract is four quarters, as suggested by empirical evidence (e.g., Taylor (1999)), and $\varepsilon_{w}=4$, so that a 1 percent rise in relative nominal wages would result in a 4 percent fall in relative hours worked, in light of the microeconomic evidence presented by Griffin $(1992,1996)$ (see also Huang and Liu (2002)). Again, we consider $\eta=2$ and $\gamma=0$ as a baseline calibration.

Figure 4 examines the initial responses of hours worked and the real wage as $\eta$ varies in the range between 1 and 5 and $\gamma$ in the range between 0 and 1 . With both sticky wages and sticky prices, a positive technology shock is always followed on impact by a modest increase in the real wage, whether the Frisch elasticity of labor supply and the degree of policy accommodation are high or low. The initial percentage increase in the real wage is quite consistent with the empirical evidence we have reported in section 2 . The inability of a pure sticky-wage model to generate the observed decline in hours might be overcome by combining sticky wages with sticky prices, but then the extent of policy accommodation matters. With weak policy accommodation, hours fall when technology improves, while if policy accommodation is relatively high, hours rise.

In light of the microeconomic evidence that prices change fairly frequently, we also consider a shorter price-contract duration of 2 quarters as well as the standard calibration of 4 quarters. Figure 5 plots the impulse responses of hours and the real wage following a positive technology shock, with various degrees of price rigidity. In the extreme case where price decisions are perfectly flexible, hours does not change as we have shown analytically. When prices adjust once every 2 quarters on average, hours falls. Increasing the duration of price contracts to 4 quarters magnifies the fall in hours. The response of the real wage stays positive as we vary the degrees of price rigidity, although the initial response is more dampened as the length of price contracts increases. In this sense, the model with nominal wage rigidity, along with some price rigidity, is potentially more successful than a RBC model augmented with real frictions, a pure sticky-price model or a pure sticky-wage in explaining the evidence about the adjustment of hours and the real wage to a technology shock.

\section{The Extent of Monetary Accommodation}

Since the predictions of both the sticky-price model and the model with sticky wages and sticky prices depend on how accommodative monetary policy is, it is important get a sense of how large $\gamma$ has been during the postwar period. That is, how accommodative was U.S. monetary policy 
to technology shocks? One way to answer this question is to examine the relation between the growth rate of a measure of U.S. money aggregates and an appropriate measure of technology shocks. Without loss of generality, we use M2 as a measure of U.S. money aggregate, with a sample period from 1959 to 2003 (at monthly frequency). This series is obtained from the FRED II database published by the St. Louis Federal Reserve Bank. We use two alternative measures of technology shocks. The first measure is constructed by Galí and Rabanal (2004) with a sample period from 1950 to 2002 (at quarterly frequency), and the second is the "purified" technology measure constructed by BFK (2006), which has a sample period from 1949 to 1996 (at annual frequency).$^{9}$

Figure 6 presents scatter plots of M2 growth rate and the two alternative measures of technology shocks, with appropriate data frequencies and sample periods. The plots suggest a weak correlation between the money growth rate and the technology measures. In other words, $\gamma$ is likely to be small.

To obtain a formal estimate of $\gamma$, we run an OLS regression of the M2 growth rates on the technology shock series. In particular, we estimate the monetary policy rule specified in (16), which, for ease of reference, is rewritten here:

$$
\mu_{t}=(1-\rho) \bar{\mu}+\rho \mu_{t-1}+\gamma \varepsilon_{t} .
$$

Using Galí-Rabanal's technology measure, the point estimates are $\hat{\rho}=0.61(0.06)$ and $\hat{\gamma}=0.10(0.05)$, where the numbers in parentheses are standard errors. Using the BFK measure produces point estimates of $\hat{\rho}=0.60(0.14)$ and $\hat{\gamma}=0.13(0.33)$. It appears that the estimates for $\gamma$ are small and may even be statistically insignificant. This also provides the basis for our baseline calibration of $\gamma=0 .^{10}$

Going back to Figure 3, which plots the impact effects of technology shocks on hours and real wages in the sticky-price model, we see that even if we use the higher point estimate of $\gamma=0.13$, the response of the real wage is still negative for all values of $\eta$. On the other hand, going back to Figure 4, which plots the impulse responses in the benchmark model with sticky prices and nominal wages, we see that the impact responses of hours and real wage are broadly consistent with empirical evidence for plausible values of $\gamma$.

\section{Conclusion}

Ever since the seminal work of Lucas and Rapping (1969), accounting for fluctuations in employment and the real wage has been considered a decisive test for macroeconomic models. We have taken up

\footnotetext{
${ }^{9}$ We are grateful to Susanto Basu and Jordi Galí for kindly providing us with the data.

${ }^{10} \mathrm{We}$ have also used M1 data in the regression and obtained very similar results (not reported).
} 
this challenge from the perspective of a DSGE model driven by productivity (neutral technology) shocks. Our main message is clear: neither the standard RBC model nor a RBC model augmented with real frictions passes this test, but a DSGE model featuring both nominal wage and nominal price rigidities does.

Put in the broader context of current research with DSGE models, our findings could have other important implications. For a long time, macroeconomists have considered that certain types of models were better suited for the analysis of certain types of shocks. RBC models for which nominal rigidities had little practical relevance were believed to be the main vehicle from which the transmission of technology shocks could be analyzed. On the other hand, New Keynesian models built around nominal rigidities were thought to be particularly useful to improve our understanding of the monetary transmission mechanism.

We believe the findings presented in this paper regarding the transmission of productivity shocks and those from the recent DSGE literature on monetary transmission speak of a single voice. Working from a money-driven DSGE model, Christiano, Eichenbaum and Evans (2005) have shown that nominal wage and nominal price rigidities are both important to understand the macroeconomic effects of monetary policy shocks: with sticky prices only, the effects of a monetary policy shock on output are weak at best, while with sticky wages only, an expansionary policy shock is followed by a sharp decline of inflation that lasts about a year. Therefore, the research program on monetary policy and productivity shocks has now come full circle: nominal rigidities matter to understand the sources of business cycle fluctuations.

\section{References}

Basu, Susanto and Fernald, John G. "Aggregate Productivity and Aggregate Technology." European Economic Review, June 2002, 46(6), pp. 963-991.

Basu, Susanto; Fernald, John G. and Kimball, Miles S. "Are Technology Improvements Contractionary?" American Economic Review, December 2006, 96(5), pp. 1418-1448.

Bils, Mark and Klenow, Peter J. "Some Evidence on the Importance of Sticky Prices." Journal of Political Economy, October 2004, 112(5), pp. 947-985.

Calvo, Guillermo A. "Staggered Contracts in a Utility-Maximizing Framework." Journal of Monetary Economics, 1983, 12, pp. 383-398.

Christiano, Lawrence J., Eichenbaum, Martin and Vigfusson, Robert. "What Happens After A Technology Shock?" Mimeo, Northwestern University, August 2004. 
Fernald, John. "Trend Breaks, Long-Run Restrictions, and the Contractionary Effects of Technology Shocks." Journal of Monetary Economics, 2007, 54, pp. 2467-2485.

Fischer, Stanley. "Long-term Contracts, Rational Expectations, and the Optimal Money Supply Rule." Journal of Political Economy, 1977, 85, pp. 191-205.

Fisher, Jonas D.M. "The dynamic effects of neutral and investment-specific technology shocks." Journal of Political Economy, 2006, 114, pp. 413-451.

Francis, Neville and Ramey, Valerie. "Is the Technology-Driven Real Business Cycle Hypothesis Dead? Shocks and Aggregate Fluctuations Revisited." Journal of Monetary Economics, 2005, 52, pp. 1379-1399.

Galí, Jordi. "Technology, Employment,and the Business Cycle: Do Technology Shocks Explain Aggregate Fluctuations?" American Economic Review, March 1999, 89(1), pp. 249-271.

Galí, Jordi and Rabanal, Pau. "Technology Shocks and Aggregate Fluctuations: How Well Does the RBC Model Fit Postwar U.S. Data?" NBER Macreoconomics Annual, 2004.

Galí, Jordi, Smets, Frank and Wouters, Rafael. "Unemployment in an Estimated New Keynesian Model.” 2011, Working paper, Pompeu Fabra.

Gray, Jo Anna. "Wage Indexation: A Macroeconomic Approach." Journal of Monetary Economics, 1976, 2, pp. 221-235.

Griffin, Peter. "The Impact of Affirmative Action on Labor Demand: A Test of Some Implications of the Le Chatelier Principle." Review of Economics and Statistics, 1992, 74, pp. 251-260.

Griffin, Peter. "Input Demand Elasticities for Heterogeneous Labor: Firm-Level Estimates and An Investigation Into the Effects of Aggregation." Southern Economic Journal, 1996, 62, pp. 889-901.

Huang, Kevin X.D. and Liu, Zheng "Staggered Price Setting, Staggered Wage Setting, and Business Cycle Persistence." Journal of Monetary Economics, 2002, 49, pp. 405-433.

Ireland, Peter N. "A New Keynesian Perspective on the Great Recession." Journal of Money, Credit, and Banking, 2011, 43(1), pp. 31-54.

Justiniano, Alejandro and Primiceri, Giorgio E. "The Time-varying Volatility of Macroeconomic Fluctuations." American Economic Review, 2008, 98(3), pp. 604-641.

Klenow, Pete and Kryvtsov, Oleksiy. "State-Dependent or Time-Dependent Pricing: Does It Matter for Recent U.S. Inflation?" Quarterly Journal of Economics, 2008, 123, pp. 863-904.

Kydland, Finn E. and Prescott, Edward C. "Time to Build and Aggregate Fluctuations." Econometrica, 1982, 50, pp. 1345-1370.

Liu, Zheng and Phaneuf, Louis. "Technology Shocks and Labor Market Dynamics: Some Evidence and Theory." Journal of Monetary Economics, 2007, 54, pp. 2534-2553. 
Liu, Zheng, Waggoner, Daniel and Zha, Tao. "Sources of Macroeconomic Fluctuations: A Regime-Switching DSGE Approach." Quantitative Economics, 2011 (forthcoming).

Lucas, R.E. Jr. and Rapping, Leonard. "Real Wages, Employment and Inflation." Journal of Political Economy, 1969, 77, pp. 721-754.

Nakamura, Emi and Steinsson, Jon. "Five Facts About Prices: A Reevaluation of Menu Cost Models". Mimeo, Columbia University, May 2008, forthcoming Quarterly Journal of Economics.

Pencavel, John. "The Labor Supply of Men: A Survey." in: O. C. Ashenfelter and L. Richard, eds., Handbook of Labor Economics, Vol. 1, North-Holland:Elsevier Science, 1986, pp.3-102.

Phelps, Edmund S. and Taylor, John B. "Stabilizing Powers of Monetary Policy Under Rational Expectations." Journal of Political Economy, 1977, 85, pp. 163-190.

Prescott, Edward C. "Response to a Skeptic." Quarterly Review, Federal Reserve Bank of Minneapolis, 1986, 10, pp.28-33.

Rotemberg, Julio J. and Woodford, Michael. "An Optimization-Based Econometric Framework for the Evaluation of Monetary Policy." NBER Macroeconomics Annual, 1997, pp. 297346.

Shapiro, Matthew D. and Watson, Mark W. "Sources of Business Cycle Fluctuations." NBER Macroeconomics Annual, 1988, pp. 111-148.

Smets, Frank and Wouters, Rafael. "Shocks and Frictions in US Business Cycles: a Bayesian DSGE Approach." American Economic Review, 97, pp. 586-606.

Summers, Lawrence H. "Some Skeptical Observations on Real Business Cycle Theory." Quarterly Review, Federal Reserve Bank of Minneapolis, 1986, 10, pp.23-27.

Taylor, John B. "Aggregate Dynamics and Staggered Contracts." Journal of Political Economy, 1980, 88, pp. 1-23.

Taylor, John B. "Staggered Price and Wage Setting in Macroeconomics." in: J. B. Taylor and M. Woodford, eds., Handbook of macroeconomics. Amsterdam, North Holland: Elsevier Science, 1999, Vol. 1B, pp. 1009-1050. 
Table 1.

Calibrated parameter values

\begin{tabular}{lll}
\hline Preferences: & $\eta=2$, & $\beta=0.99$ \\
Nominal contract duration: & $\alpha_{p}=0.75$, & $\alpha_{w}=0.75$ \\
Elasticities of substitution: & $\epsilon_{p}=10$, & $\epsilon_{w}=4$ \\
Money growth rule: & $\rho=0.60, \quad \gamma=0$ & \\
\hline
\end{tabular}


Hours

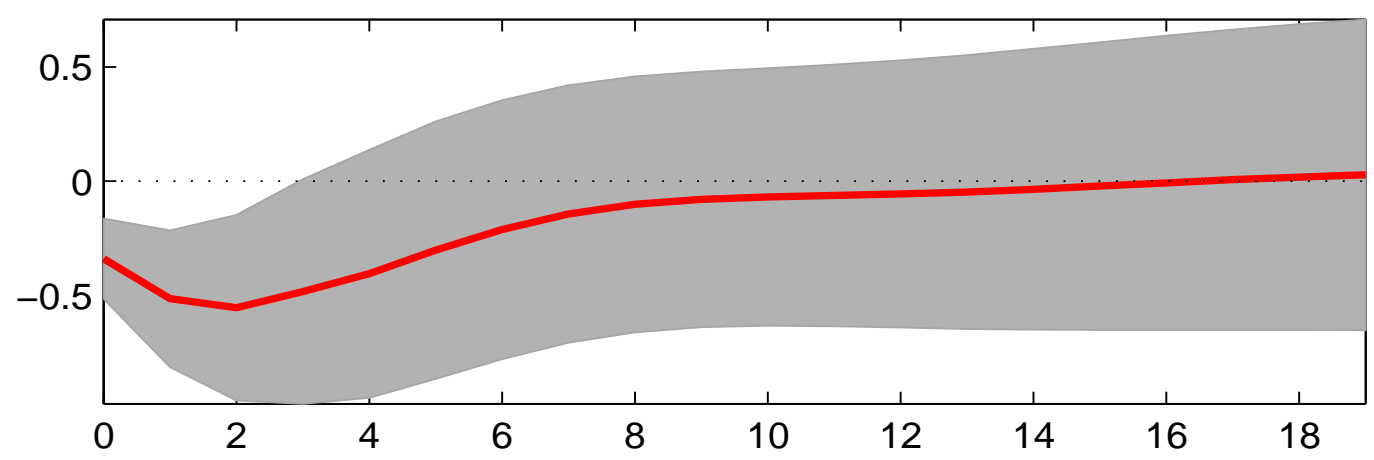

Real wage

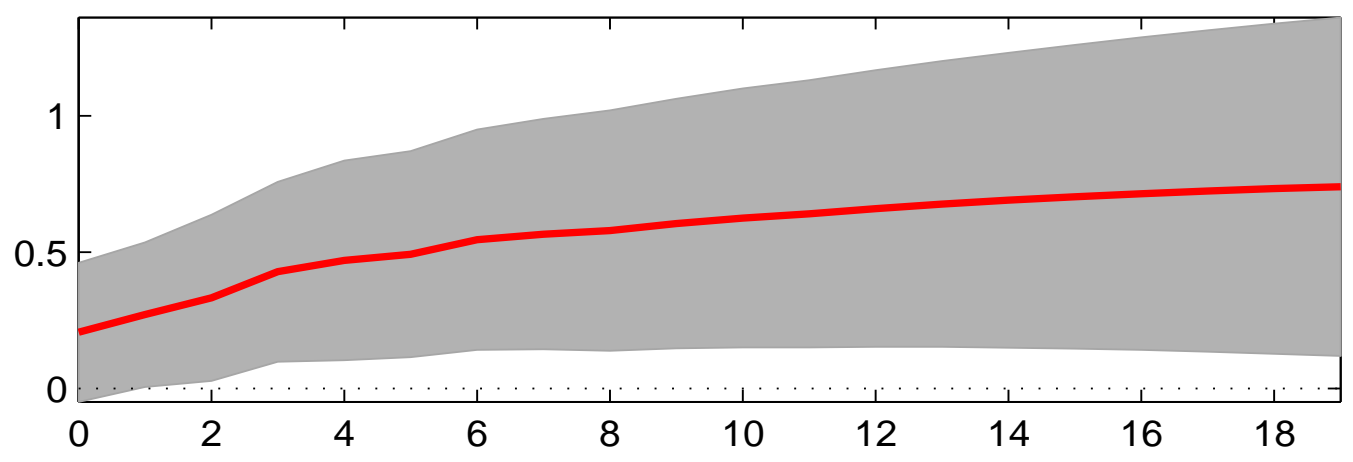

Figure 1: Impulse responses of hours and real wages to a positive technology shock in the data. 

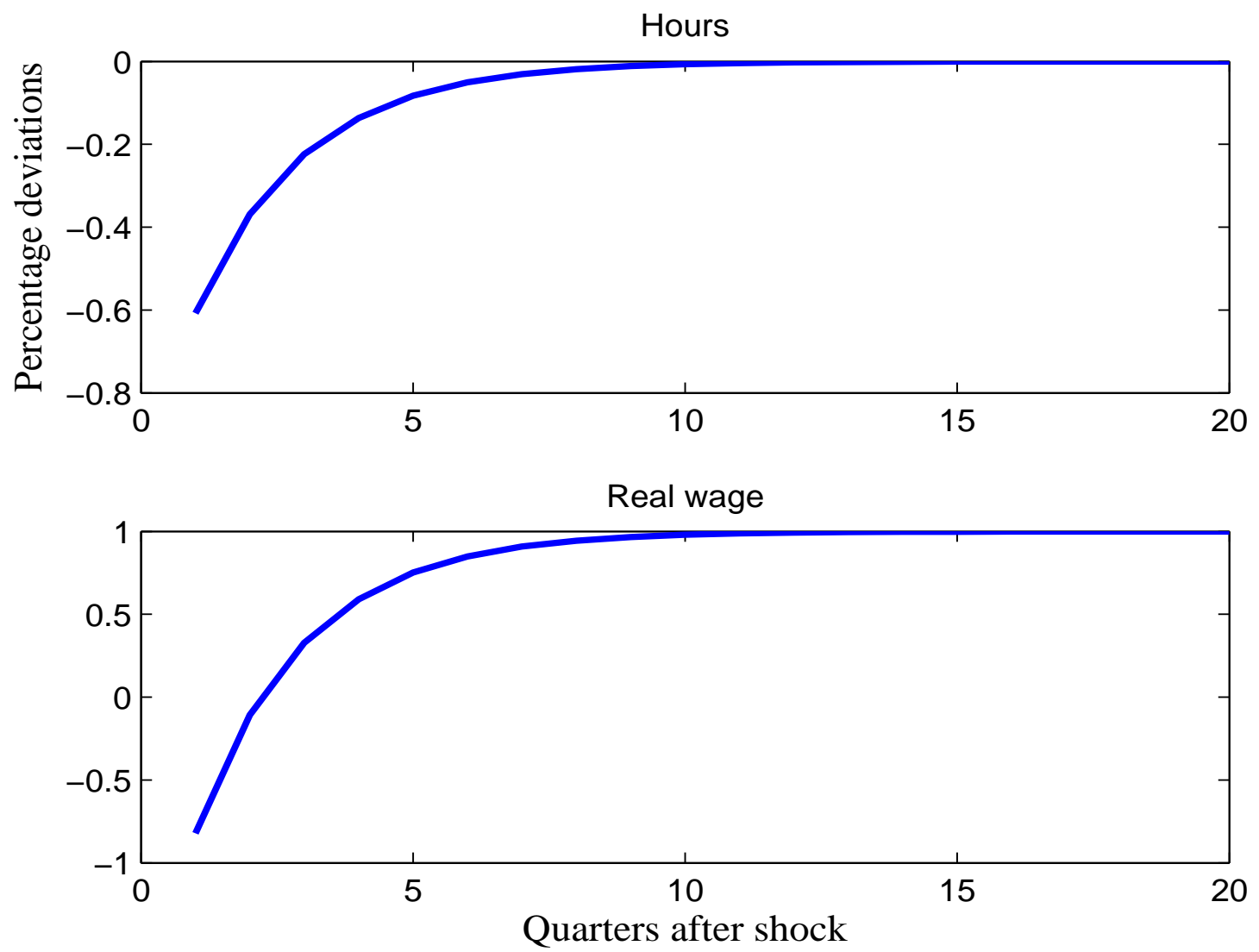

Figure 2: Impulse responses of hours and real wages to a positive technology shock in the stickyprice model. 

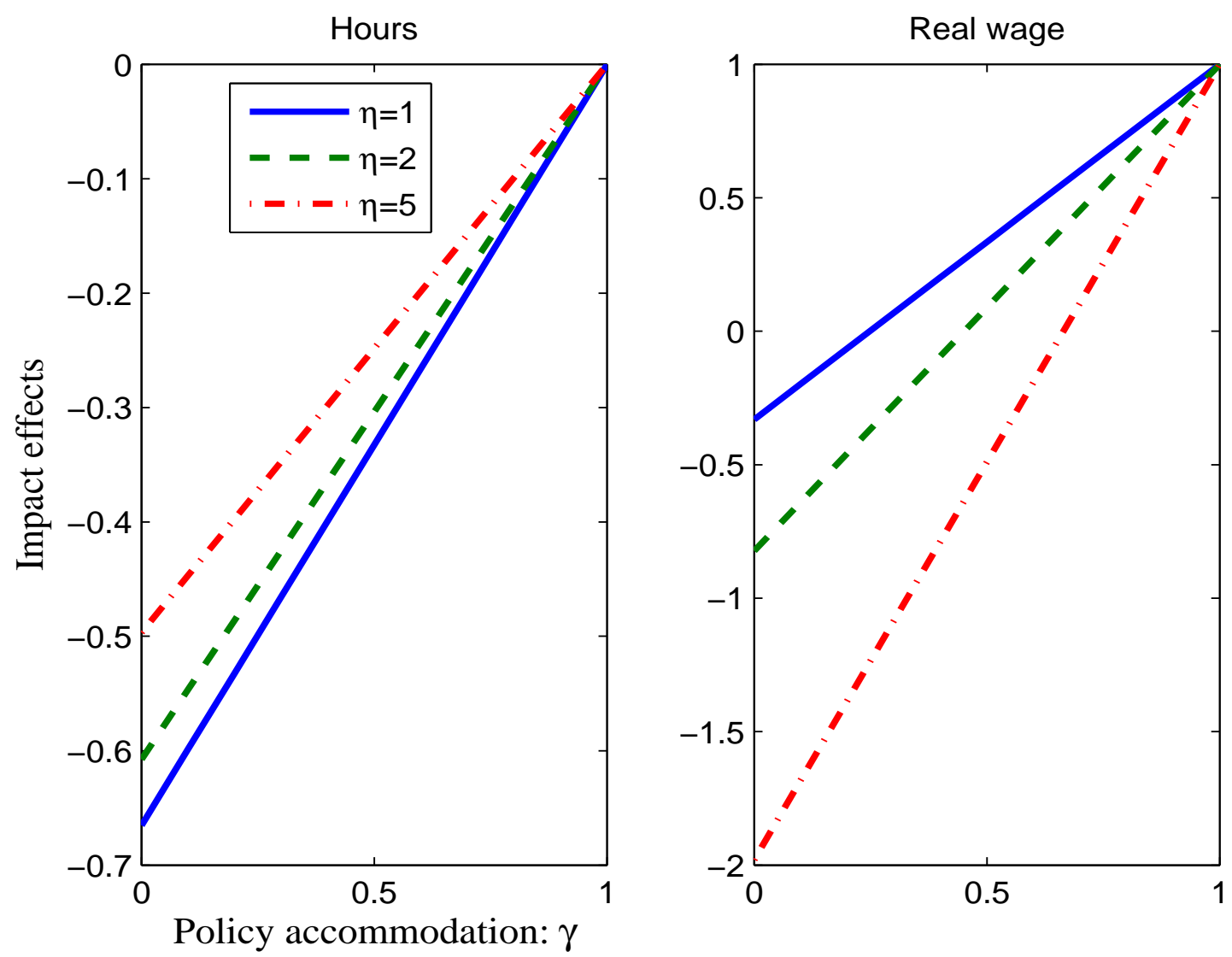

Figure 3: Impact effects of a positive technology shock on hours and real wages in the sticky-price model for various values of the Frisch elasticity of labor hours $(\eta)$ and monetary-policy accommodation $(\gamma)$. 

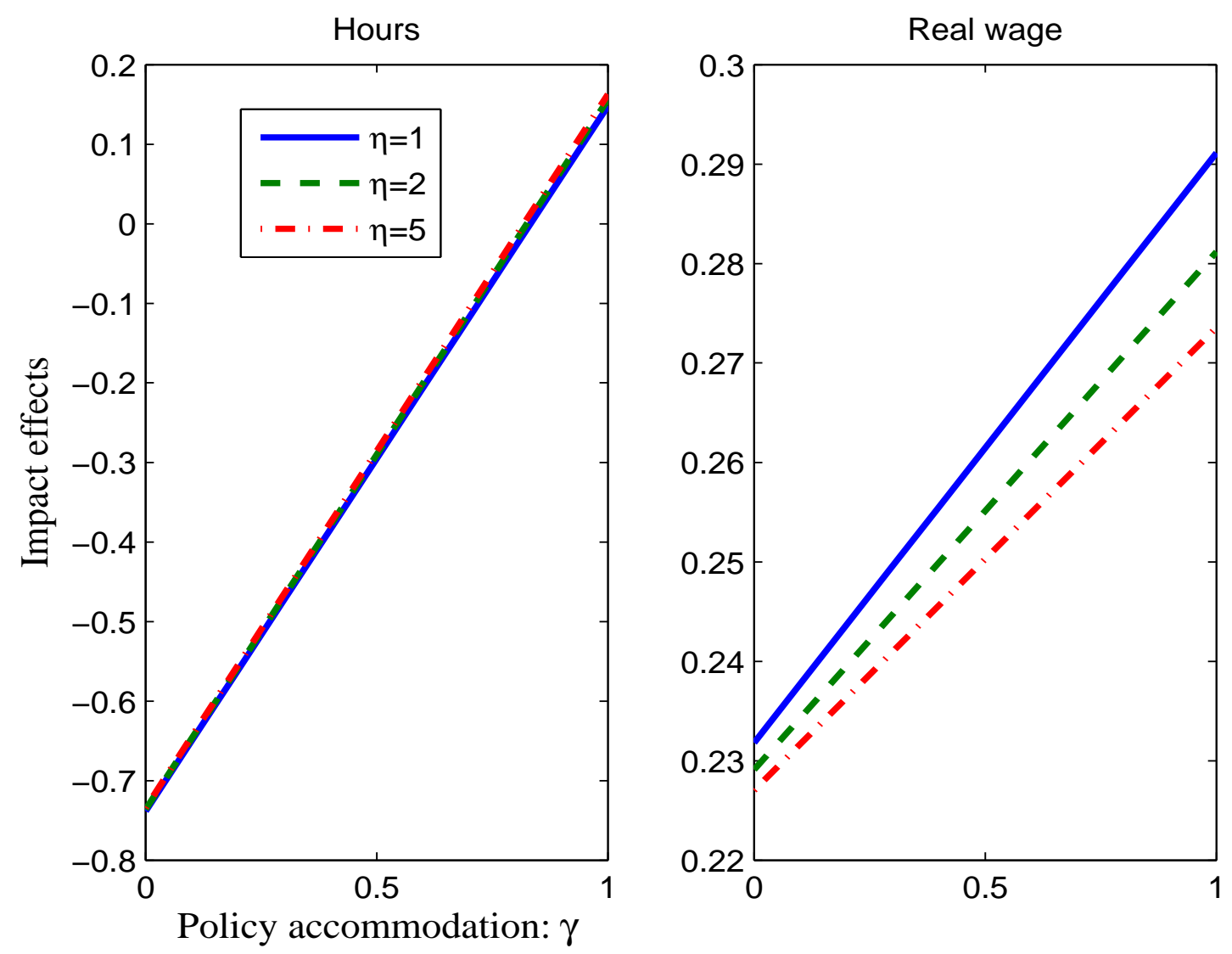

Figure 4: Impact effects of a positive technology shock on hours and real wages in the benchmark model with sticky prices and nominal wages for various values of the Frisch elasticity of labor hours $(\eta)$ and monetary-policy accommodation $(\gamma)$. 

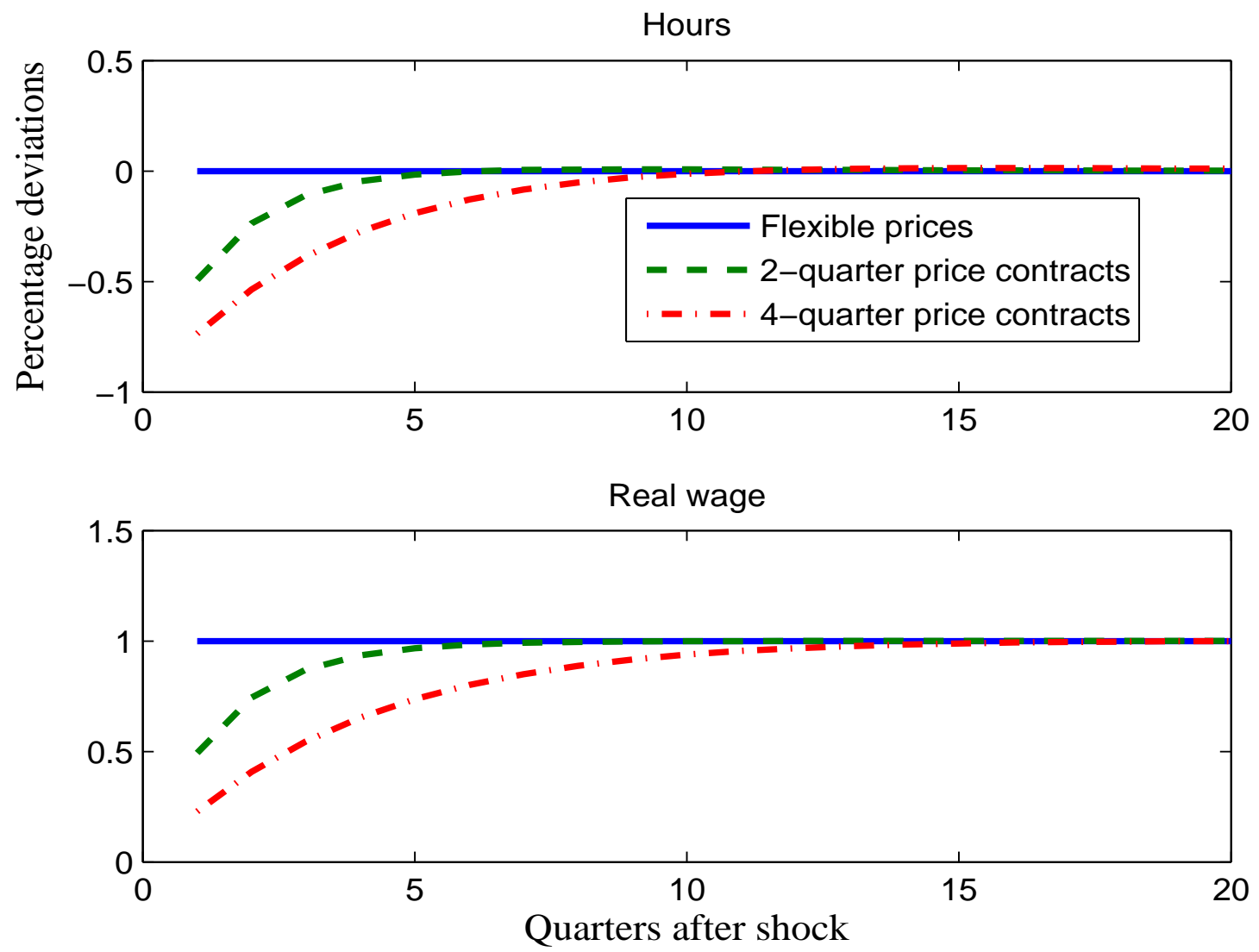

Figure 5: Impulse responses of hours and real wages to a positive technology shock in the benchmark model with sticky prices and nominal wages. 

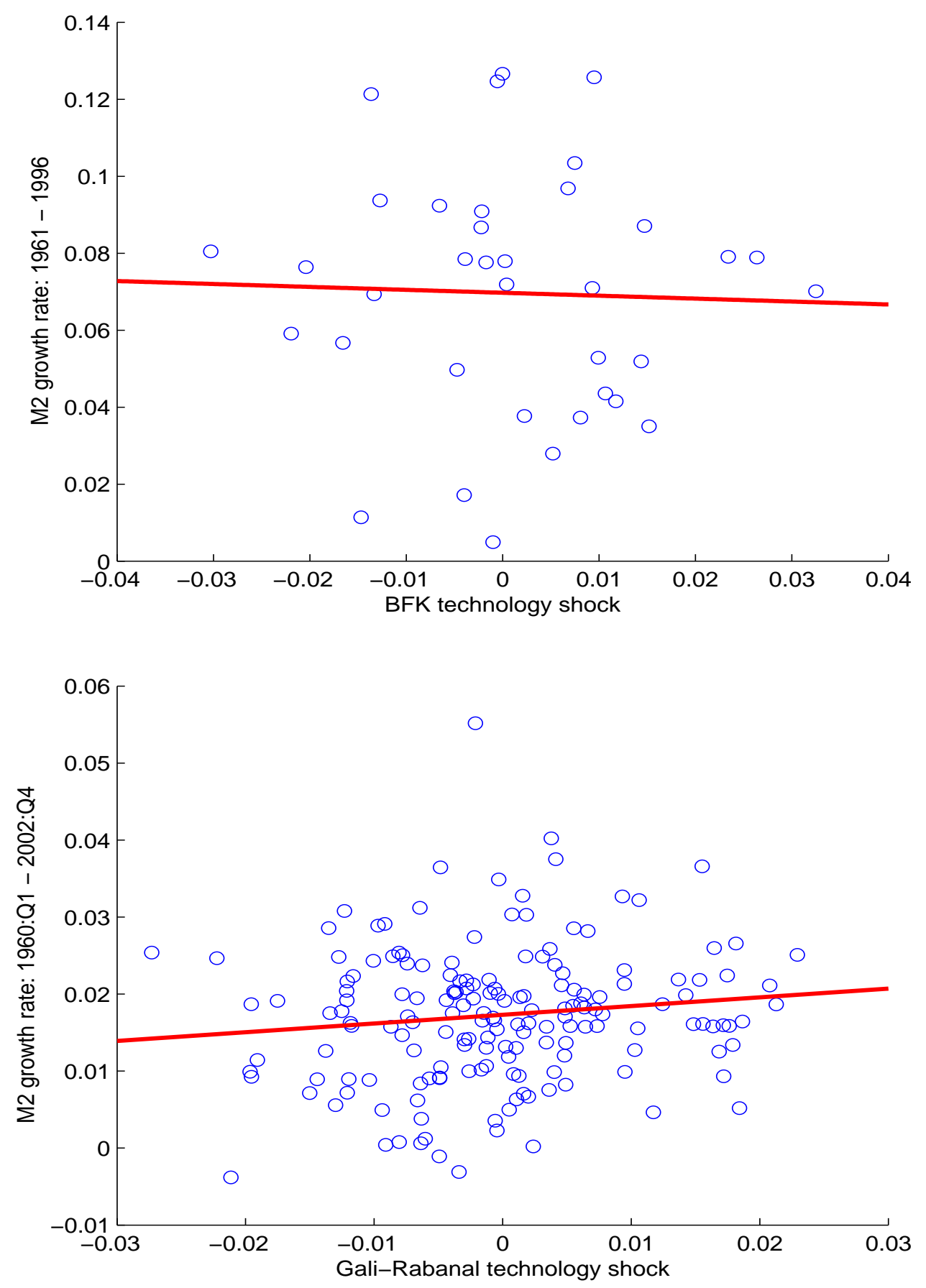

Figure 6: Money growth rate and technology shocks. The upper panel is a scatter plot of the M2 growth and the BFK (2006) technology shock (annual frequency, 1960-1996). The lower panel is a scatter plot of the M2 growth and the Gali-Rabanal (2004) technology shock (quarterly frequency, 1960:Q1 - 2002:Q4). The solid lines are the linear fits. 